\title{
リポソームを用いた新たな標的化戦略と疾患治療への応用
}

\author{
清水広介†
}

\section{Development of New Liposome Targeting Strategies for Application of Disease Therapies}

\author{
Kosuke Shimizu ${ }^{\dagger}$ \\ Department of Medical Biochemistry, School of Pharmaceutical Sciences, \\ University of Shizuoka; 52-1 Yada, Suruga-ku, Shizuoka 422-8526, Japan.
}

(Received September 8, 2016)

\begin{abstract}
Drug delivery systems (DDS) are based on the concept of providing the optimal amount of a drug to a specific area requiring treatment. Liposomes are lipid-based nanoparticles capable of encapsulating any drug into both their membrane and aqueous phases. They have the potential to be targeted when their surfaces are modified with functional molecules such as antibodies and peptides. Thus, liposomes have strong potential as drug carriers if designed for active targeting. Our research group has recently developed a new concept for liposome targeting called "reverse targeting DDS (RT-DDS)". RT-DDS differs from conventional active targeting in that the surface of the liposomes is modified with an antigenic molecule that is specifically recognized by antigen-specific immune cells. This review describes in detail the differences between these two DDS targeting concepts and proposes the application of RT-DDS to the treatment of allergies based on research using ovalbumin as a model allergy antigen.
\end{abstract}

Key words_—allergy; drug delivery system; liposome; ovalbumin; reverse targeting; splenic B cell

\section{1. はじめに}

薬物送達システム（drug delivery system; DDS)

は，疾患の治療を行うにあたり，生体に投与した薬 物が最大限の薬効を示すための目的部位に，適当な 量，そして適切な時間送達されるための技術の総称 であり, 新薬開発や原薬の安全性担保, 機能拡張,

ドラッグリポジショニングなどに向け注目を集める 研究領域である. ${ }^{1)}$ 中でも薬物キャリアを用いる方 法は, 汎用性や生産性などの点からよく利用されて いる．特に脂質二分子膜を基本構造として形成され る閉鎖小胞のリポソームは歴史が古く，素材として 生体成分を用いる点から安全性も担保されているた め，DDS 創薬のために広く利用されている。リポ ソームは粒子径や表面電荷などの調整も容易であ り，抗体，ペプチド，タンパク質，糖鎖といつた機

静岡県立大学薬学部医薬生命化学分野（干422-8526 静 岡市駿河区谷田 52-1)

現所属: ‘浜松医科大学光尖端医学教育研究センター フォトニクス医学研究部分子病態イメージング研究室 (厂431-3192 浜松市東区半田山 1-20-1)

e-mail: kshimizu@hama-med.ac.jp

本総説は, 平成 27 年度日本薬学会東海支部学術奨励賞 の受賞を記念して記述したものである.
能性分子の表面修飾も可能であることから，生体投 与後の動態制御や分子間相互作用を利用した目的部 位への標的化（アクティブターゲティング, 又は単 にターゲティングとも言う）もできるため, 薬物 キャリアとしてのリポソームの適用は, 主作用増 強, 副作用軽減を可能とするまさに薬物治療の理想 に向けた創薬と言える。 ${ }^{2}$ 本稿では, リポソーム DDS を利用した新しい標的化の概念, “逆標的化” を中心に紹介するとともに，そのアレルギー疾患治 療への応用について概説していきたい.

\section{2. 標的化 DDS の概要（標的化と逆標的化の違} (1)

一般的な標的化 DDS の概念は，標的となる部位 （例えばがん細胞）に多く発現する分子に対して特 異性かつ高い親和性を有する機能性分子（例えば抗 体）を薬物キャリア表面に修飾することで，標的部 位への送達効率の向上と非標的部位への集積回避を 企てるものであり, 薬物キャリアから標的部位へと いう一方向性の能動的な送達を示す [Fig. 1(a)]. この標的化 DDS は様々な疾患に対して適用可能で あり, 特に広く研究されている疾患ががんである. 周知の通り抗がん剂を用いるがん化学療法について 
(a)
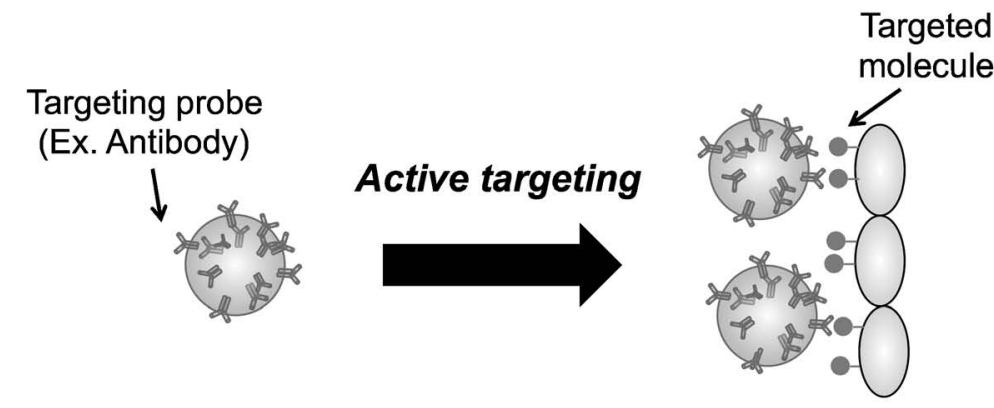

Target cells

(b)

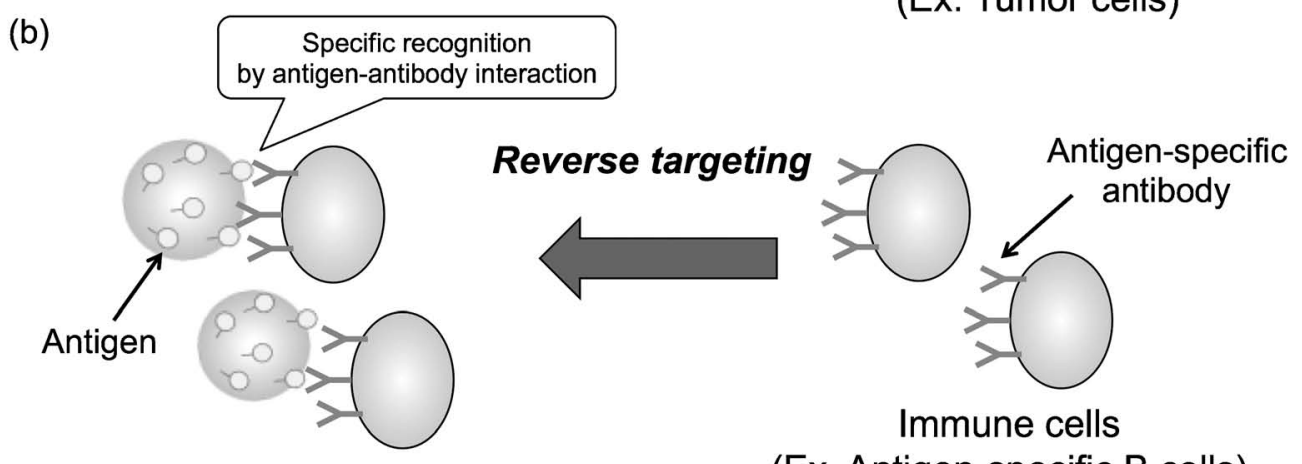

(Ex. Tumor cells)

(Ex. Antigen-specific B cells)

Fig. 1. Two Different Concepts between Conventional Active Targeting (a) and Reverse Targeting (b) DDS

は，一部のがん種に対しては明確な有効性を示すも のの，多くのがんにおいてその効果が不透明な点が あり，投与された抗がん剤の全身への非特異的分布 と薬効の細胞非特異性により, 患者の生活の質 （QOL）を著しく低下する副作用の発現が社会的問 題にまで発展している. よってがん治療における標 的化 DDS 適用のニーズは非常に高い。実際に筆者 も，がん細胞や腫瘍新生血管内皮細胞に多く発現す

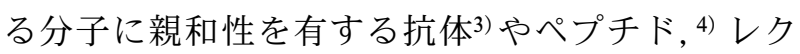
チン 5)を用いて, リポソームの固形がんへの効率的 送達に成功しており，それに伴うがん治療効果の向 上, つまり高い抗がん効果と原薬の副作用軽減効果 を明らかとしている. ${ }^{6}$

一方でわれわれの研究グループは数年前より, 通 常の標的化とは一線を画す新たな標的化概念を提唱 してきた. それが逆標的化（リバースターゲティン グ） DDS（RT-DDS）である. ${ }^{7)}$ その名の通り通常 の標的化の逆, つまり逆方向の標的化ということで ある. 前述の通り, 通常の標的化は標的に対して薬 物キャリアが積極的に結合することを示すが，逆標 的化は，むしろ薬物キャリアが標的となり，薬物を 送達したい対象となる細胞に認識してもらい薬物送 達を行うものである [Fig. 1(b)]．この標的化概念
の鍵となるのは, 生体に備わる防御機構の免疫系で ある. 詳しくは次項にて述べたい.

\section{3. 逆標的化 DDS 戦略の概要}

生体防御を担う免疫は, 生命活動を維持していく 中で必須であり，生体にとっての自己・非自己の区 別は緻密に制御されている. 例えばウイルスやバク テリア自体, またその感染細胞は, 非自己つまり異 物（抗原）として認識され排除される一方，生体を 組織する正常な細胞は, 自己として認識されること で免疫監視から逃れることができている.これに対 し免疫系の異常, 例えば非自己に対する過剩な炎症 反応は, 様々なアレルギー疾患やアナフィラキシー を発症し，また自己の非自己化は自己免疫疾患発症 につながり，命を脅かすことも少なくないため，免

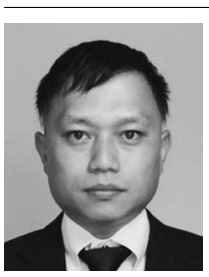

清水広介
浜松医科大学光尖端医学教育研究セン 夕ー・准教授, 博士 (薬学). 2003 年 静岡県立大学大学院薬学研究科博士前 期課程修了. 2005 年同後期課程中退 後, 同大学薬学部・助手. 助教, 講師 を経て，2016 年 10 月より現職. 2015 年日本薬学会東海支部奨励賞, 2016 年 日本 DDS 学会奨励賞受賞など. 研究 領域はリポソーム DDS. 趣味はキャン プ等多数. 


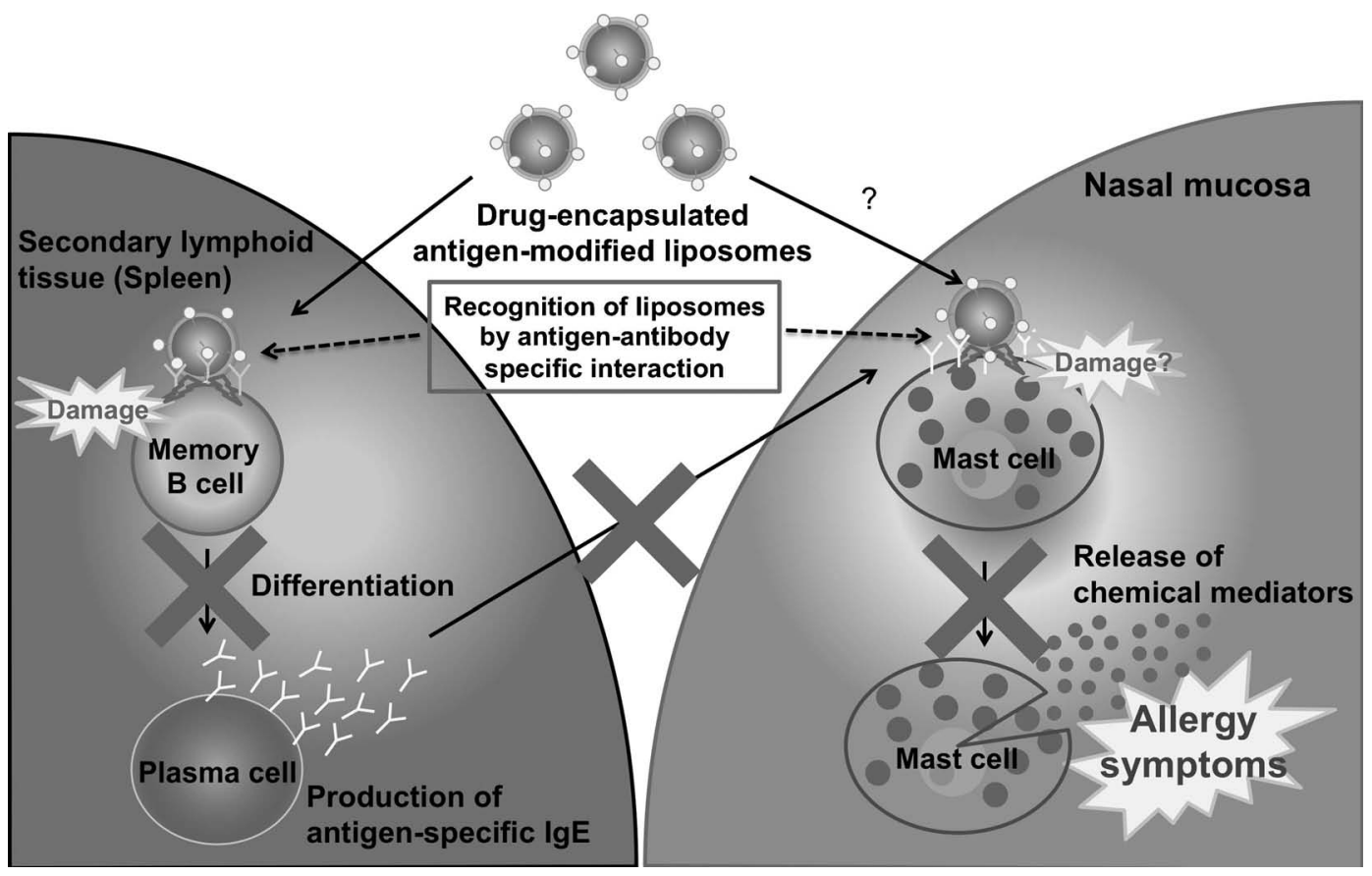

Fig. 2. Scheme of Therapeutic Strategy for Allergic Diseases Using RT-DDS

疫反応において異物に対する認識特異性はいかに重 要となっているかがわかる. われわれはこの免疫を 担う細胞群の抗原に対する緻密に制御された認識に 着目し，その認識特異性を逆手に取って抗原を認識 する免疫担当細胞群に薬物を効率よく送達する新た な DDS 技術として，逆標的化を提案した。この逆 標的化を利用した疾患治療を考えた場合，その 1 つ としてアレルギー疾患治療への応用が挙げられる. 通常，花粉症を代表とする即時型アレルギーは，抗 原に初回暴露されて免疫が成立した生体に再度抗原 に曝される際，その抗原に対して特異的な抗体（主 として IgG 抗体）を表面に発現する脾臓内 B 細胞 に認識され，形質細胞へと分化した後に抗原に対す る特異的 IgE 抗体を分泌し，その IgE 抗体が鼻腔 などの粘膜に存在する肥満細胞膜上に結合, そして その抗体が抗原と相互作用した際に，ヒスタミンを 含むケミカルメディエーターが分泌され，くしゃみ などの花粉症症状が引き起こされる．われわれの逆 標的化戦略は, アレルギーの抗原となる分子（アレ ルゲン）をリポソーム表面に修飾したリポソーム (逆標的化リポソーム) を投与することで, リポソー ム表面の抗原を介してリポソームを特異的に免疫担 当細胞に認識させ，その際内封する薬物を細胞に送 達することで，アレルギー発症に係わる免疫担当細
胞群を障害するものである. ${ }^{7)}$ 特に抗原特異的抗体 の分泌を担う脾臓内 B 細胞を障害すれば, ${ }^{8)}$ アレル ギー発症までの下流のカスケードにも影響を与える ことができ，長期間花粉症の発症を抑えることがで きるであろうという仮説を立て，検討を行った (Fig. 2). 実際の研究結果については次項に述べる.

\section{4. 逆標的化リポソームの調製と標的性評価}

抗原を表面に付与した逆標的化リポソームを作製 するにあたり，アレルギ一疾患のモデル抗原として 広く用いられている，オボアルブミン（ovalbumin; OVA）を選択した。リポソームは，生体への全身 投与後目的の部位まで安定に内封薬物を送達でき る，ジパルミトイルホスファチジルコリン (DPPC) を基本脂質組成とするものを用い，粒子径について はエクストルーダーを用いて体内動態特性が良好な $130 \mathrm{~nm}$ 前後に調整した。また OVA のリポソーム への表面修飾は, タンパク質修飾によく用いられる $N$-スクシンイミドを反応基としてポリエチレング リコール（polyethylene glycol; PEG）鎖の末端に 有する脂質誘導体 (DSPE-PEG-NHS) を，リポソー ムとOVAとのリンカー分子として用い, DSPEPEG-NHS にOVA を反応させた後, リポソームと 混合することで行った。 得られた OVA 修飾リポ ソームには，リポソーム 1 個あたり OVA が約 400 


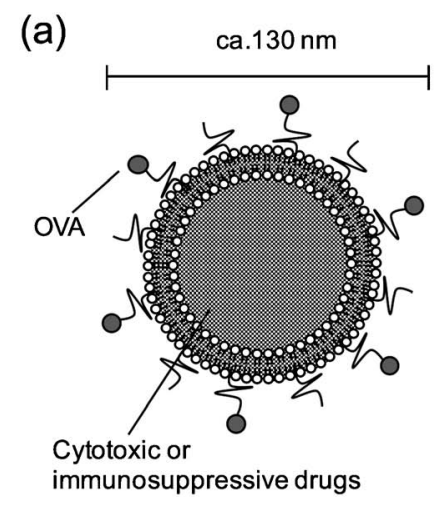

(c)

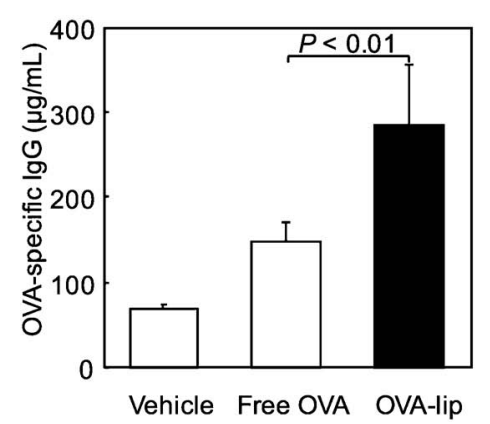

(b)

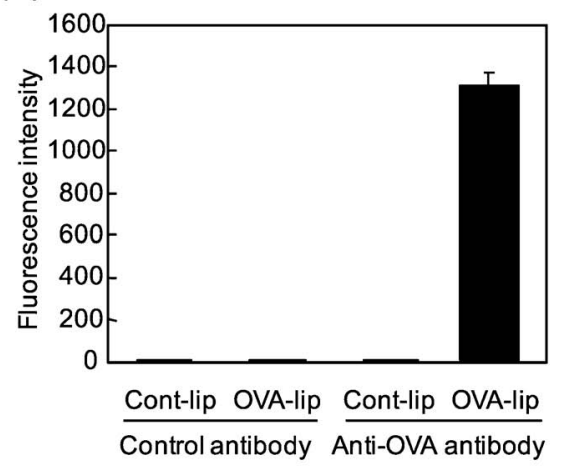

(d)

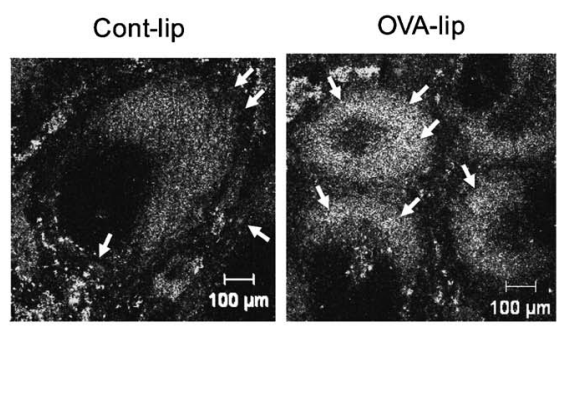

Fig. 3. Targeting Potential of OVA-modified Liposomes to Splenic B Cells in OVA-sensitized Mice

(a) Preparation of ovalbumin (OVA)-modified liposomes (OVA-lip). (b) Specific interaction of OVA-lip with anti-OVA antibody. Fluorescently labeled unmodified liposomes (Cont-lip) or OVA-lip were added to the wells coated with OVA-specific antibody, and the fluorescence intensity was measured. (c) Induction of OVA-specific IgG antibody production by OVA-lip injection to OVA-sensitized mice. OVA-sensitized mice were intravenously injected with $0.3 \mathrm{~m}$ glucose (vehicle), free OVA, or OVA-lip at days 8, 10, and 12 after OVA sensitization. At day 14, the amount of OVA-specific IgG antibody in the serum was measured by ELISA. (d) Co-localization of OVA-lip with splenic B cells. Fluorescently labeled Cont-lip or OVA-lip was intravenously injected to OVA-sensitized mice and the spleen sections were probed with Alexa488-conjugated anti-mouse IgG antibody for detecting B cells. The distribution of liposomes was observed under a confocal laser-scanning microscope. Arrows indicate the accumulation of liposomes.

分子結合していることが計算上求められており，抗 原としてリポソームが認識されるためには十分で あった [Fig. 3(a)]. 実際 OVA 修飾リポソームと OVA 特異的抗体との結合性を調べたところ，抗 OVA 抗体に対して OVA 修飾リポソームは効率よ く結合した一方，コントロール抗体には結合を示さ なかつたため [Fig. 3(b)], 逆標的化リポソームの 標的性は，リポソームに表面修飾された抗原とそれ に対する特異的抗体との分子間相互作用によるもの であることを明らかとした．また，この逆標的化リ ポソームが OVA としての抗原性を有しているかを 調べるために，OVA で事前に感作したマウスに OVA 修飾リポソームを尾静脈内投与し, その後血 中の抗 OVA 抗体価の測定を行ったところ，OVA 修飾リポソームの投与により, 抗 OVA 抗体価が有 意に上昇することを明らかとし，投与した OVA 修 飾リポソームが抗原として認識され, 抗原特異的抗 体産生が誘導されることが示された [Fig. 3(c) ]. ${ }^{9}$
さらに蛍光標識 OVA 修飾リポソームを OVA 感作 マウスに尾静脈内投与し, その後の脾臟内における リポソームの分布の観察を行ったところ, OVA 未 修飾リポソームでは脾臟内 $\mathrm{B}$ 細胞領域（抗 $\mathrm{IgG}$ 抗 体にて染色）の周辺に多く存在していたのに対し, OVA 修飾リポソームは, B 細胞領域と共局在する ことを明らかとした [Fig. 3(d)].さらにアレル ギ一発症過程において特に重要であり, 外来抗原に 対する特異的抗体を産生する場として知られる胚中

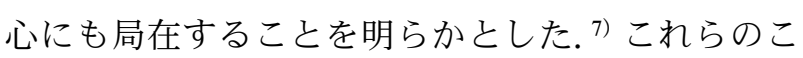
とから, 抗原を表面修飾する逆標的化リポソーム は, 抗原として免疫担当細胞に認識され, 抗原特異 的な抗体産生を担う $\mathrm{B}$ 細胞を標的化できることが 示唆された.

\section{5. 逆標的化を利用したアレルギー疾患治療}

前項にて調製した逆標的化リポソームを，アレル ギ一疾患治療に適用するためには薬物の封入が必要 となる. 本戦略は長期的なアレルギー発症を抑える 
(a)

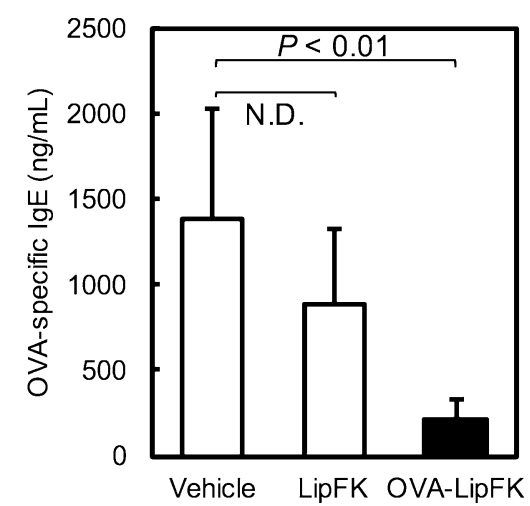

(b)

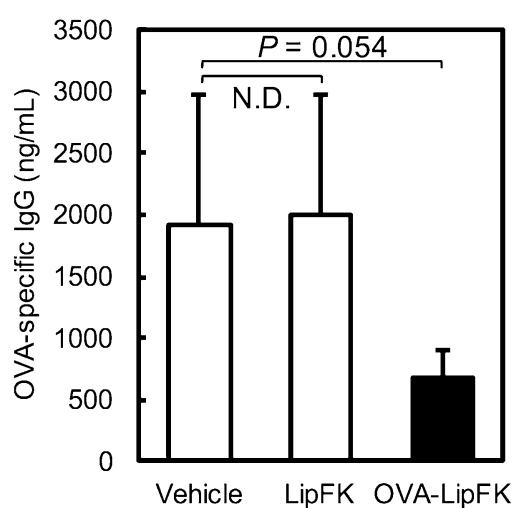

Fig. 4. Anti-allergic Effect of FK506-encapsulated OVA-lip

OVA-sensitized mice were intravenously injected with $0.3 \mathrm{~m}$ sucrose (vehicle), FK506-encapsulated Cont-lip (LipFK), or FK506-encapsulated OVA-lip (OVALipFK, $5 \mu \mathrm{g} / \mathrm{kg} / \mathrm{d}$ as FK506 dosage) at days 14, 16, and 18 after the OVA sensitization. At day 21, OVA was intraperitoneally injected for boosting and the amounts of OVA-specific $\operatorname{IgE}$ (a) and $\operatorname{IgG}(\mathrm{b})$ antibodies in the serum were measured at day 28 .

ことを目的とするため, 抗原特異的な免疫担当細胞 に直接的な障害を与える細胞障害性薬剤や免疫抑制 剂が内封薬物として有効である，われわれは細胞障 害性薬剂としてドキソルビシン，免疫抑制剤として FK506 を選択し，OVA 感作マウスに対する治療実 験を行った。本稿では FK506 を用いた検討結果に ついて紹介させて頂く. OVAの腹腔内投与によっ て感作したマウスに, FK506 投与量として $5 \mu \mathrm{g} / \mathrm{kg} / \mathrm{d}$ となるように感作から $14 ， 16 ， 18$ 日後に OVA 未 修飾の FK506 封入リポソーム（LipFK），又は OVA 修飾 FK506 封入リポソーム（OVA-LipFK） を尾静脈内投与した。 その後 21 日目に OVA を追 加免疫した際の血中抗 OVA 抗体価を ELISAにて 測定することにより，アレルギー治療効果を評価し た。結果として，OVA-LipFK を処置することによ り, OVA 特異的 IgE 抗体並びに $\mathrm{IgG}$ 抗体の産生が 強く抑制されることを見い出した (Fig. 4). ${ }^{10)}$ 通常 FK506 を全身の免疫抑制を目的として使用する場 合, $1 \mathrm{mg} / \mathrm{kg}$ 以上の投与が必要となるが, 本標的化 戦略ではごく微量の薬物投与量で，抗原特異的な免 疫反応を抑制できることを明らかとした。 なお，抗 原修飾リポソーム投与によるアナフィラキシーの発 症や，体重減少等の副作用はみられておらず，本治 療法の安全性も示唆されている.これらの結果から 逆標的化を利用した DDS 戦略は，アレルギ一疾患 治療において有用であることが示めされた.

6. おわりに

本稿では新たな標的化概念, 逆標的化 DDS のア
レルギー疾患治療への応用について紹介させて頂い た。本稿では OVA をモデル抗原として用いた成果 を示させて頂いたが，現在スギ花粉の主要抗原であ るC Cry j 1 を用いた逆標的化リポソームを調製し, スギ花粉症治療への試みも行っており，実際に良好 な結果を得ている. また, 更なる適用拡大として, 難治性の自己免疫疾患への応用にも挑戦し始めてお り,リポソーム DDS を利用した新たな治療戦略の 確立に向け, 今後も多くのエビデンスを増やしてい きたいと考えている. 本研究成果が免疫疾患の新た な治療法として一石を投じるものとなれば幸いであ る.

謝辞本研究を遂行するにあたり，ご指導，ご 鞭撻を賜りました静岡県立大学薬学部 奥 直人教 授に心より感謝申し上げます。また本研究は，静岡 県立大学薬学部医薬生命化学教室にて実施され, 浅 井知浩准教授, 小出裕之助教, 木村純子特任助教か らのご協力・ご助言, そして何よりも教室所属の学 生, 大学院生, 卒業修了生が研究室にて手を動かし て得た研究結果となります。この場をお借りして深 謝申し上げます。また本研究は，科学研究費補助金 を始めとする様々な助成金，また共同研究先からの 多大なご支援により行われました。ここに御礼申し 上げます。

利益相反＼cjkstart開示すべき利益相反はない. 


\section{REFERENCES}

1) Allen T. M., Cullis P. R., Science, 303, 18181822 (2004).

2) Allen T. M., Cullis P. R., Adv. Drug Deliv. Rev., 65, 36-48 (2013).

3) Nishikawa K., Asai T., Shigematsu H., Shimizu K., Kato H., Asano Y., Takashima S., Mekada E., Oku N., Minamino T., J. Control. Release, 160, 274-280 (2012).

4) Sugiyama T., Asai T., Nedachi Y. M., Katanasaka Y., Shimizu K., Maeda N., Oku N., PLoS One, 8, e67550 (2013).

5) Ikemoto K., Shimizu K., Ohashi K., Takeuchi Y., Shimizu M., Oku N., Cancer Sci., 107, 5359 (2016).
6) Shimizu K., Asai T., Oku N., Expert Opin. Ther. Targets, 9, 63-76 (2005).

7) Ichikawa K., Asai T., Shimizu K., Yonezawa S., Urakami T., Miyauchi H., Kawashima H., Ishida T., Kiwada H., Oku N., J. Control. Release, 167, 284-289 (2013).

8) Cinamon G., Zachariah M. A., Lam O. M., Foss F. W. Jr., Cyster J. G., Nat. Immunol., 9, 54-62 (2008).

9) Ichikawa K., Urakami T., Yonezawa S., Miyauchi H., Shimizu K., Asai T., Oku N., Int. J. Pharm., 336, 391-395 (2007) .

10) Shimizu K., Miyauchi H., Urakami T., Yamamura-Ichikawa K., Yonezawa S., Asai T., Oku N., J. Drug Target., 24, 890-895 (2016). 